\title{
Neurovascular development and links to disease
}

\author{
Christiana Ruhrberg $\cdot$ Victoria L. Bautch
}

Received: 15 January 2013 / Revised: 28 January 2013 / Accepted: 28 January 2013 / Published online: 12 March 2013

(C) The Author(s) 2013. This article is published with open access at Springerlink.com

\begin{abstract}
The developing central nervous system (CNS) is vascularized via ingression of blood vessels from the outside as the neural tissue expands. This angiogenic process occurs without perturbing CNS architecture due to exquisite crosstalk between the neural compartment and invading blood vessels. Subsequently, this intimate relationship also promotes the formation of the neurovascular unit that underlies the blood-brain barrier and regulates blood flow to match brain activity. This review provides a historical perspective on research into CNS blood vessel growth and patterning, discusses current models used to study CNS angiogenesis, and provides an overview of the cellular and molecular mechanisms that promote blood vessel growth and maturation. Finally, we highlight the significance of these mechanisms for two different types of neurovascular CNS disease.
\end{abstract}

Keywords Neurovascular - Neural tube - Retina . Hindbrain · VEGF · Semaphorins · Neuropilin · GPCR124 · TGF $\beta$

C. Ruhrberg $(\bowtie)$

UCL Institute of Ophthalmology, University College London, 11-43 Bath Street, London EC1V 9EL, UK

e-mail: c.ruhrberg@ucl.ac.uk

\section{L. Bautch $(\triangle)$}

Department of Biology, The University of North Carolina at Chapel Hill, Chapel Hill, NC 27599, USA

e-mail: bautch@med.unc.edu

V. L. Bautch

McAllister Heart Institute, The University of North Carolina at Chapel Hill, Chapel Hill, NC 27599, USA

V. L. Bautch

Lineberger Comprehensive Cancer Center, The University of North Carolina at Chapel Hill, Chapel Hill, NC 27599, USA

\section{Introduction}

The vertebrate central nervous system (CNS), comprised of brain, spinal cord, and retina, is vascularized during its development to provide oxygen and nutrients to newly born neurons, long before they extend axons and dendrites. The neural tube acquires its own vascular network prior to birth via angiogenic sprouting from vessel networks that form immediately outside the CNS; the intraneural blood vessel network then expands as the neural tissue grows. In contrast, the multilayered retina is initially supplied by a combination of two extra-retinal vascular systems, the choroidal vasculature that supplies the outer retina, and the hyaloid arteries that supply the inner retina and lens; the choroidal vasculature persists, but late in mammalian development, the hyaloid arteries are replaced with a dedicated intraretinal vascular system. In this review, we will provide a historical perspective on research into neural tube and retinal angiogenesis, discuss current models available to study CNS angiogenesis, and summarize recent progress in uncovering the cellular and molecular mechanisms of blood vessel growth and maturation in the CNS.

\section{Description of neurovascular development}

Historic perspective

The process of CNS vascularization was first studied in the fetal chick brain and both rat and rabbit cerebral cortex with a combination of India ink perfusion and electron microscopy to reveal the structure of patent blood vessels [1-3]. In combination with conventional histological techniques, these studies revealed that blood vessels first form a perineural vascular plexus (PNVP), and then invade and branch 
within the neural tube in stereotypical patterns. Subsequent electron microscopy studies of spinal cord vascularization in the developing mouse embryo demonstrated interactions between endothelial cells and neural cells, and suggested that both cell types contribute to the blood-brain barrier (BBB) [4].

Following on from the pioneering studies, subsequent research into the mechanisms of CNS vascularization used antibody-based and embryological techniques to trace the behavior of developing blood vessels in the neural tube. Initially, the QH1 antibody, which recognizes quail angioblasts and endothelial cells [5], was used to analyze avian vascularization [6]. QH1 staining allowed researchers to follow the fate of quail endothelial cells after transplantation into chick hosts and provided strong evidence that the CNS was vascularized by angiogenic sprouting [7-9]. More recently, staining for QH1 and in situ hybridization have been combined with neural tube electroporation to selectively manipulate one side of the avian neural tube, with the contra-lateral side serving as an internal control $[10,11]$.
Since the discovery of QH1, additional vascular markers have become available that facilitate the study of brain and retinal angiogenesis in other vertebrates, including mouse. Accordingly, immunohistochemical, immunofluorescent, and immunoblotting techniques are now commonly combined with traditional methods to study the molecular and cellular mechanisms of vessel growth in the CNS. In particular, immunological techniques have been used to compare CNS angiogenesis in normal development and after genetic modification of candidate vascular growth and patterning factors.

Not long after the discovery of brain vascularization through angiogenic vessel ingression, it was shown that a comparable mechanism also operates in the mammalian retina, with angiogenic vessel ingression from the optic nerve vasculature $[12,13]$. Currently, the perinatal mouse retina is the most widely studied model system for studying CNS vascularization (reviewed in [14]), followed by the mouse embryo hindbrain [15] (Fig. 1). The popularity of these models results from the genetic tractability of the mouse embryo, the ever-increasing availability of antibodies for
Fig. 1 Time course of blood vessel ingression into the mouse embryo hindbrain and the perinatal mouse retina. a Vessels sprout from the PNVP into the hindbrain at around embryonic day 9.75 in the mouse and then grow radially towards the ventricular zone. Radial vessels do not invade the subventricular zone, but sprout laterally and then anastomose to form a subventricular vascular plexus by E12.5. b Cross section of an adult eye shows the relationship of retinal vessels to other ocular structures (top half) and the subdivision of the retinal vasculature into three plexi, termed superficial (or primary plexus), intermediate plexus and deep plexus. c Retinal vascularization proceeds from center to periphery in a radial fashion during the first week of life (upper half) and leads to an extensively remodeled superficial plexus (lower half) a

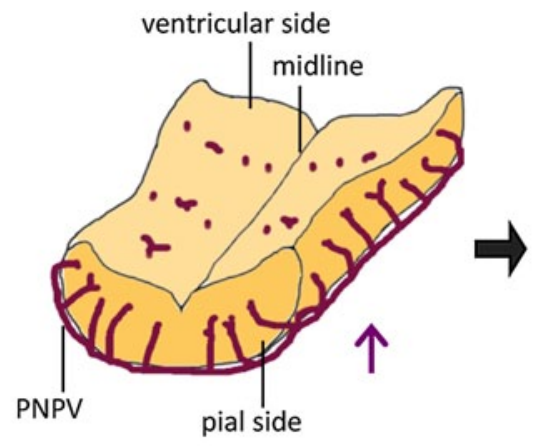

b

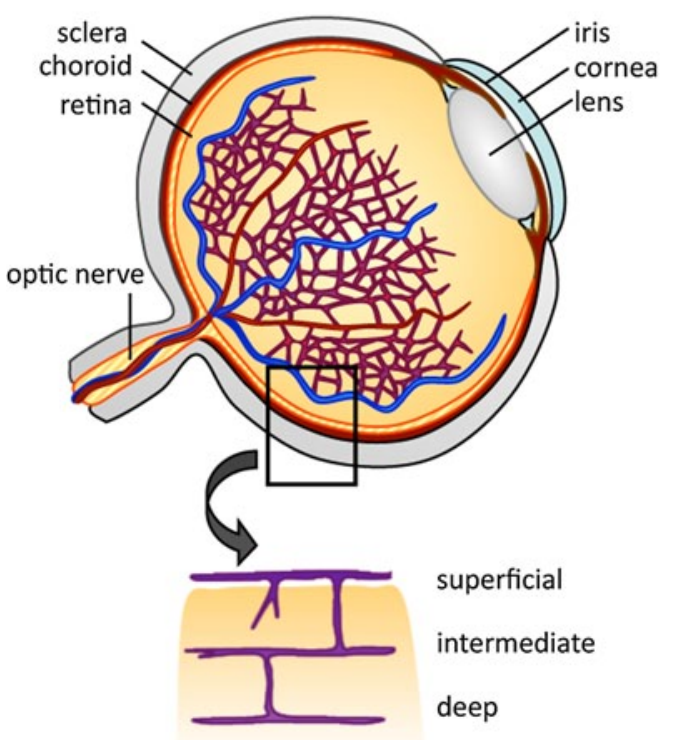

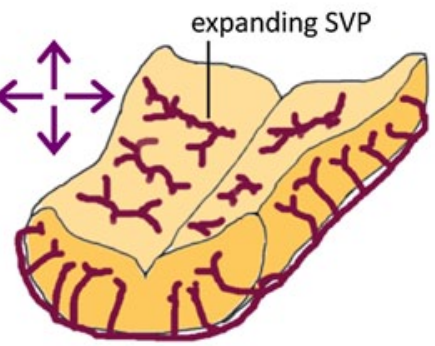

c

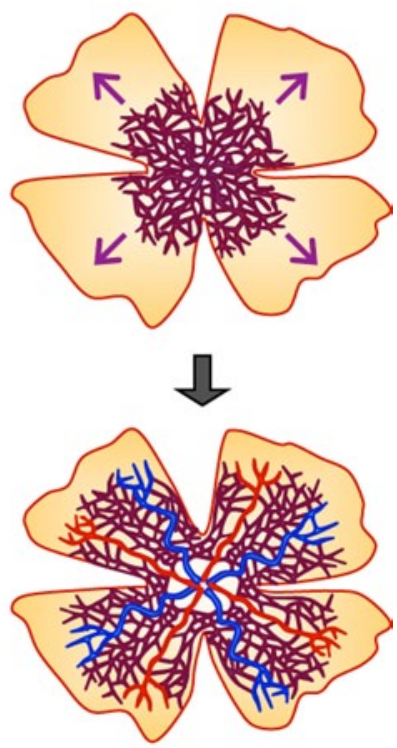


relevant mouse proteins, and the ability to perform quantitative studies on flat-mounted tissues. A model system that complements and diversifies the use of immunolabeled mouse tissues is the zebrafish embryo, because several fluorescent transgenic reporters for endothelial cells have been developed for live imaging of vascular development $[16,17]$. For example, transgenic fish that link GFP or mCherry to vascular promoters such as $k d r l(f l k l)$ or $f l i l$ are used extensively, and can be used to study CNS vascularization in normal and genetically altered fish embryos.

Description of CNS vascularization: hindbrain and retina models

The vascularization of the mouse embryo hindbrain is initiated around embryonic day (E) 9.5, when a few vascular sprouts emerge from the PNVP and invade the hindbrain parenchyma (Fig. 1a, left-hand side; e.g., [18]). At E10.25, these radially growing vessels begin to sprout at near right angles and extend parallel to the hindbrain surface that faces the fourth ventricle (Fig. 1a, right-hand side). As sprouts from neighboring radial vessels meet and anastomose, the subventricular vascular plexus (SVP) is formed (Fig. 1a, right-hand side) $[15,18]$. This vascular fusion process is promoted by yolk sac-derived tissue macrophages, which interact with endothelial tip cells and thereby act as bridge cells between neighboring vessel sprouts [18]. By E12.5, an extensive vascular network has been established in the hindbrain, consisting of radial vessels originating from the perineural plexus and the SVP that is placed orthogonally to the radial vessels [15]. Following on from these early stages, sprouting and fusion moves to deeper brain layers, but the precise events that drive this process are not yet understood.

Vascularization of the avian neural tube occurs in a similar manner $[1,9,10]$. At the limb level, the PNVP forms between Hamburger Hamilton $(\mathrm{HH})$ stages 16 and 24 (E2.5-4.5) in the quail, with ingression beginning at $\mathrm{HH}$ stages 22-24 (E4-4.5). The ingression points are not exact, but cluster around a ventral and more lateral point on each side of the midline [10]. The ingressing vessels migrate dorsally or medially until they reach the subventricular zone, where they branch at right angles, extend, and anastomose to enable circulation $[1,4]$. Early work suggested that brain vascularization in the chick does not involve angioblastic single cell precursors [19]. However, QH1 labels single, ramified cells in the quail dorsal neural tube that interact with nascent vessels [9]. These cells were originally proposed to be angioblasts, but were subsequently shown to be macrophages that interact with vascular endothelium [20] and likely correspond to the tissue macrophages that promote the fusion of neighboring vessel sprouts in the mouse embryo hindbrain [18].
In contrast to the hindbrain and neural tube, the retina is vascularized only after birth in rodents to give rise to a system of three vascular plexi that are interconnected (Fig. 1b; reviewed in [14]). Vascularization begins on the day of birth, when vessel sprouts emerge from the optic nerve head and spread radially over the retina, guided by a template of astrocytes (Fig. 1c), with blood vessels and astrocytes forming co-patterned networks [21-23]. During the process of radial expansion, the primary plexus undergoes arteriovenous differentiation (Fig. 1c; reviewed by [14]). After the first week of life, vessel sprouts emerge from this primary retinal vessel plexus to dive into the inner retinal layers at near right angles and form the deep plexus in week two and then the intermediate plexus in week three after birth (Fig. 1b, lower half; reviewed by [14]). While the contribution of astrocytes to primary plexus formation has been extensively studied, the cellular scaffolds that guide vessel sprouting into the deeper retinal layers are still poorly defined. As observed in the hindbrain, vascular anastomosis of retinal blood vessels is promoted by macrophages [18, 24-26]. Retinal macrophages also contribute to subsequent vascular remodeling in the retina. Thus, the decrease in initial vascular network complexity is compensated for by pruning of fewer vessel segments at later developmental stages in $C s f 1^{o p / o p}$ mutants with defective macrophage recruitment, or $\mathrm{PuI}^{-/-}$mutants lacking macrophages [18]. Consequently, the adult retinal vasculature reaches normal complexity in $C s f 1^{o p / o p}$ mutants that survive to adulthood [24].

Due to the increasing availability of useful markers, precise genetic mutations in proteins regulating blood vessel growth, the planar orientation of sprouting blood vessels and the proximity of the emerging vessel plexus to the tissue surface, both the mouse hindbrain and retina models allow excellent visualization of vessel growth. It is therefore not surprising that these CNS regions have replaced the rat and rabbit cortex as preferred models to study CNS vascularization. However, not all vertebrates have a retinal vasculature [13, 27], and certain aspects of vessel patterning may be unique to the cortex. Accordingly, one study provided evidence that cell autonomous programs regulated by Hox genes lead ventral sprouts to colonize dorsal areas of the telencephalon, rather than sprouting from the dorsal PNVP [28].

An emerging model of neurovascular development is the zebrafish, which is particularly amenable to rapid genetic manipulation and longitudinal live imaging [17]. Two recent studies have described the process of hindbrain vascularization in the zebrafish embryo $[29,30]$. The spatial relationship of vessel ingression sites and rhombomere boundaries in the zebrafish hindbrain suggests neurovascular cross-talk [30] that appears to be conserved in other vertebrates, although this is less well studied. In this context, it is interesting that rhombomere boundaries in the chick are 
extracellular spaces rich in growth factor-binding proteoglycans $[31,32]$.

Cellular behaviors and interactions in neurovascular development

Like elsewhere in the body, blood vessels in the CNS are comprised of endothelial cells that are invested with mural cells. Although common to other vascular beds, some of the underlying principles that govern cellular interactions of endothelial cells amongst each other and with mural cells were first elucidated using the retina and hindbrain models, such as the tip cell-stalk cell paradigm (reviewed in [33]).

Endothelial tip cells respond to signals by initiating migration, while endothelial stalk cells follow behind the tip cell and respond to signals with proliferation and lumen formation to form the main body of new vascular sprouts. Initial experiments linked tip cell and stalk cell behaviors to signals provided by the vascular endothelial growth factor VEGF-A (referred to as VEGF in the remainder of this review) [15, 34]. Subsequent studies showed that VEGF interacts with the delta like 4 (DLL4)/notch pathway to regulate tip cell vs. stalk cell number [35-37]. Studies of chimeric embryoid bodies and developing retinal vessels suggested that tip cell and stalk cells do not remain fixed, but switch phenotypes over time [38]. Accordingly, the tip and stalk cell phenotypes are plastic states of functional specialization.

Consistent with a key role for VEGF in tip cell induction in the retina and hindbrain in vivo, a high level of VEGFR2 and low level of VEGFR1 relative to neighboring endothelial cells promotes tip cell behavior in chimeric embryoid bodies [38]. Recent work identified additional regulators of vessel sprouting and tip cell behavior, for example BMP signaling [39-41] and SEMA3E signaling through PLXND1 (discussed in more detail below) [42]. Several tip cell markers have also been identified via expression analysis, and their function in CNS angiogenesis is presently being characterized [43, 44].

In addition to the general principles of angiogenesis described above, specialized cellular interactions between endothelial and non-endothelial CNS cells create a unique structure called the neurovascular unit. In this structure, endothelial cells form firm junctions with each other and interact with other cell types to create the BBB; this barrier maintains CNS homeostasis and is also thought to regulate CNS blood flow and synaptic activity [45, 46]. A hallmark of CNS vessels is the expression of the glucose transporter GLUT1. Mutations in the GLUT1 gene that lead to GLUT1 deficiency cause a rare autosomal dominant disorder characterized by a low cerebrospinal fluid glucose concentration due to reduced transport across the BBB [47].

In addition to endothelial cells, the neurovascular unit contains pericytes, astrocytes, oligodendrocytes, and microglia. Two recent studies showed that loss of pericytes in the CNS elevates endothelial transcytosis [48, 49]. Accordingly, pericyte-endothelial interactions are necessary to maintain the BBB by preventing exchange across the endothelium, complementing the role of tight intra-endothelial cell junctions in preventing paracellular exchange. The molecular cross-talk among the cell types of the neurovascular unit is only partially characterized, but is regulated by TGF $\beta$, PDGF, BMP, and integrins; accordingly, disruption of these signaling axes perturbs the BBB [48-53].

\section{Key signals regulating CNS angiogenesis}

Although many signaling pathways contribute to vascular development in general, we focus here on key pathways that are critical for the cross-talk between the nervous and vascular systems to regulate blood vessel patterning in the CNS.

\section{VEGF}

Several neural cell types produce VEGF, and neuroglial VEGF is required for the ingression of blood vessels into the developing neural tube and retinal vascularization across different vertebrate species (e.g., [10, 29, 54-57]). VEGF is differentially spliced to produce isoforms with a differential affinity for the surrounding extracellular matrix [58], and their bioavailability is further regulated by proteolytic mechanisms [59, 60]. Amongst these isoforms, VEGF121 is the most diffusible, VEGF189 binds the matrix most avidly, and VEGF165 has intermediate properties. Cleavage of the VEGF189 isoforms by matrix metalloproteases leads to the generation of the VEGF113, which is released from the matrix. Whereas the human isoforms are termed VEGF121, VEGF165, and VEGF189, reflecting the number of amino acid residues in the mature protein, the corresponding mouse isoforms are one amino acid residue shorter and therefore termed VEGF120, VEGF164, and VEGF188, respectively.

In the CNS, genetic manipulations that lead to expression of only a single VEGF isoform do not prevent ingression, but affect vessel patterning and morphogenesis. Accordingly, hindbrain vessels in Vegfa $a^{120 / 120}$ mice expressing only the VEGF120 isoform have a larger caliber and branch infrequently, while vessels in Vegfa ${ }^{188 / 188}$ mice expressing only VEGF188 are thin and over-branched [15]. In the quail in the neural tube, the localized over-expression of matrix binding VEGF165 or VEGF189, but not VEGF121, also leads to ectopic vessel ingression at the site of over-expression, whilst local VEGF blockade prevents ingression [10].

In the neonatal mouse retina, a collection of the three VEGF isoforms is produced and displayed by an astrocytic network that is located beneath the expanding vascular plexus (e.g. $[23,61])$. However, astrocyte-derived VEGF is 
not essential for the initial vascular growth of retinal vessels, but instead for the survival of nascent retinal vessels [62] and hypoxia-induced neovascularization in a mouse model of oxygen induced retinopathy [63]. While astrocytederived VEGF alone is not essential for angiogenic sprouting in the developing retina, the more widespread deletion of VEGF from the neuroretina severely perturbs retinal angiogenesis [55]. It is not yet known if one specific cell type provides an essential VEGF cue, or if multiple cell types provide redundant sources of VEGF.

The tyrosine kinase FLK1 (KDR, VEGFR2) is the main signal transducing VEGF receptor in endothelial cells in vitro and essential for endothelial cell survival and blood vessel formation, with its loss leading to embryonic lethality at E9.5 in the mouse (reviewed in [64]). Due to their early embryonic lethality, Flkl knockout mice are not suitable to study the specific roles of FLK1 signaling in CNS vascular development. However, use of a function-blocking antibody revealed that FLK1 is essential for tip cell formation and vascular outgrowth in the retina [34]. FLK1 was originally thought to be a critical mediator of VEGF-A-induced DLL4 expression and signaling in sprouting retinal blood vessels; however, a recent study showed that when Flkl is deleted in endothelial cells, retinal angiogenesis depends on the alternative VEGF family receptor tyrosine kinase FLT4 (VEGFR3), which is best known for its role as a VEGF-C receptor in lymphangiogenesis [65].

Neuropilins, neuropilin-binding VEGF-A isoforms, and semaphorins

Neuropilin 1 (NRP1) is a non-catalytic transmembrane protein whose genetic loss, either globally or specifically in endothelial cells, severely inhibits CNS vascularization, as shown for mouse in the spinal cord [66], hindbrain [67], and forebrain [68]. In contrast, the perisomatic regions, located outside the CNS, are vascularized in the absence of NRP1, with only minor morphological defects [15]. It is not yet known why NRP1 is essential for CNS vascularization, but less important for some other vessel beds. Relevant to CNS vascularization, NRP1 serves as a receptor for VEGF165 and a member of the structurally unrelated class 3 semaphorin family termed SEMA3A (reviewed in [69]). Both ligands bind to distinct NRP1 domains and can therefore bind simultaneously, rather than competitively [70]. VEGF121 can also bind NRP1, but with 50-fold lower affinity than VEGF165, due to the absence of an exon 7-encoded domain that enhances binding [71].

Both VEGF165 and SEMA3A have been implicated as modulators of endothelial cell behavior. However, studies of mouse knockouts lacking SEMA3A have shown that this NRP1 ligand is dispensable for normal brain vascularization and blood vessel formation elsewhere in the developing mouse [72, 73]. In agreement, inactivation of semaphorin binding to NRP1 does not affect brain angiogenesis or vascular development in the early mouse embryo. Moreover, co-ablation of the related neuropilin NRP2, which also serves as a VEGF and SEMA receptor, to abrogate all semaphorin signaling through NRP1 and NRP2, does not affect CNS vascularization $[72,74]$.

The above studies did not identify roles for SEMA3A in developmental angiogenesis, but tumor studies implicated SEMA3A as a modulator of pathological angiogenesis. Thus, SEMA3A reduces the overall vascularity of tumors and "normalizes" tumor vessels, in part by recruiting myeloid cells that stimulate vessel maturation [75]. Moreover, high concentrations of SEMA3A evoke vascular permeability in the skin of adult mice by stimulating signaling through plexin-NRP1 complexes [76], which are better known for their role in neural guidance during development (reviewed in [69]). Whether these findings on the role of SEMA3A in the adult vasculature are also relevant to CNS blood vessels has not yet been examined.

Semaphorin signaling through NRP1 does not impair brain vascularization, but loss of NRP1 from endothelial cells causes vascular brain defects similar to those caused by loss of NRP1 in all cell; accordingly, it was proposed that VEGF-A rather than SEMA3A signaling through NRP1 is essential for vascular development [68]. Yet, direct evidence that NRP1 serves as a VEGF164 receptor in angiogenesis is still lacking. In this context, it is interesting to note that Vegfa ${ }^{120 / 120}$ mice lacking heparin/neuropilin binding VEGF isoforms have milder CNS vascular defects than mice lacking NRP1 [15, 67]. This observation raises the possibility that NRP1 promotes brain angiogenesis through additional, but as yet unidentified, signaling mechanisms. In vitro, NRP1 interacts with a host of additional proteins, including several growth factors and adhesion molecules [77-81]. Which of these interactions are physiologically relevant to CNS vascularization remains to be determined.

SEMA3E is the only class 3 semaphorin that does not bind to a neuropilin receptor, but instead binds directly to the plexin PLXND1 [74]. In the developing retinal vasculature, high VEGF levels emanating from the avascular retinal periphery induce PLXND1 expression in endothelial cells at the vascular front in a VEGFR2-dependent manner [82]. Loss-of-function studies further demonstrated that SEMA3E, derived from the neural layers of the retina, signals through endothelial PLXND1 to upregulate DLL4 at the vascular front, which in turn increases endothelial Notch signaling to a loss of tip cells and tip cell filopodia [82]. Consequently, normal vascular expansion into the retinal periphery is disrupted in mice lacking SEMA3E [82]. Even though SEMA3E does not directly bind to NRP1, in CNS neurons NRP1 can convert SEMA3E/PLXND1mediated axonal repulsion into attraction [83]. Whether 
similar mechanisms operate in endothelial cells to modulate SEMA3E signaling is not known. Remarkably, SEMA3E normalizes VEGF-A-induced pathological vessel growth in a mouse model of oxygen-induced retinopathy, in which retinal vessels grow abnormally into the vitreous [84]. Thus, the intravitreal administration of SEMA3E protein prevented this abnormal vessel growth and instead normalized vessel growth within the retina. This observation makes SEMA3E a potential therapeutic tool to fine tune VEGF-A signaling and vascular growth in the ischemic nervous system.

\section{Other neurovascular signals}

Several additional signaling pathways have recently been identified as important for CNS angiogenesis, with roles in blood vessel ingression and/or survival. The genetic loss of both WNT7a and WNT7b reduces neural tube angiogenesis, and utilizes the canonical $\mathrm{Wnt} / \beta$-catenin pathway, as vascular-specific loss of $\beta$-catenin resulted in reduced neural tube vessels, and those that ingressed were dilated and hemorrhagic $[85,86]$. Effectors of Wnt signaling in CNS angiogenesis may include the death receptors DR6 and TROY, which are downstream transcriptional targets of $\mathrm{Wnt} / \beta$-catenin signaling that are also required for proper brain angiogenesis and BBB formation [87].

Several studies revealed a requirement for the orphan G protein coupled adhesion receptor GPCR124 in endothelial cells for proper neural tube vascularization [88-90]. Specifically, loss of GPCR124 in mice delays but does not completely prevent blood vessel ingression. Moreover, abnormal glomeruloid tufts and hemorrhages are associated with defective BBB formation in the absence of GPCR124. Interestingly, GPCR 124 is downstream of TGF $\beta$, whose loss has also been linked to defective CNS angiogenesis and a compromised neurovascular unit [91]. Finally, mouse knockout studies showed that $\alpha v \beta 8$ integrin expression by neural, but not endothelial cells is required for normal CNS vascularization and to prevent hemorrhage at later embryonic and postnatal stages $[51,52,92]$. Because integrins have been shown to act upstream of TGF $\beta$ signaling, it appears likely that integrin expression in neural cells stimulates TGF $\beta$ signaling in endothelial cells, which initiates GPCR124 expression for proper neurovascular development.

\section{Neurovascular diseases}

The many facets of neurovascular disease have recently been reviewed extensively [93]. Here, we discuss the recent progress in identifying the molecular and cellular mechanisms of two types of brain disease, cerebral cavernous malformations (CCMs) and brain cancer.

\section{$\mathrm{CCM}$}

Cavernous hemangiomas in the brain consist of thin-walled, fragile blood vessels with poor blood flow that are known as CCMs. They are caused by mutations in proteins that are important for cerebral vascular integrity (reviewed in [94, 95]). Three distinct heterozygous familial mutations in CCM1 (KRIT1), CCM2 (MGC4607, OSM), or CCM3 (PDCD10) predispose to CCM formation, with a second, somatic hit likely leading to loss of heterozygosity and disease manifestation [96]. Sporadic CCM has also been linked to these three genetic loci. Recent work shows that CCM1 stabilizes endothelial cell junctions via the small GTPase RAP1 and that CCM1/CCM2 interactions are required for this junctional stabilization [97]. The reasons for the prevalence of these vascular malformations in CNS endothelium are not yet understood, but may relate to the unique properties of the BBB and neurovascular unit.

\section{Cancer}

Although cancerous brain cells emerge independently of the brain vasculature, the close functional relationships between CNS vessels and neural cells can lead to brain tumors that are highly vascularized and difficult to treat, primarily in the case of glioblastoma (reviewed in $[98,99]$ ). Recently, several provocative studies provided evidence that tumor cells can mimic endothelial cell behavior to form vascular channels [100], and that tumor cells can even differentiate into endothelial cells that line blood vessels in glioblastoma [101-103]. It was further hypothesized that a tumor-initiating stem/progenitor cell might be the source of tumorderived vascular cells ([101-103]; reviewed in [98]).

\section{Conclusions and unanswered questions}

The cellular interactions and molecular signals critical for CNS vascularization and the formation of the neurovascular unit are being elucidated at an accelerating speed, and we are beginning to appreciate the significance of defective vascular development for the emergence of CNS pathologies. Yet, it is likely that additional signaling mechanisms and interactions remain to be identified before we will fully understand how the cross-talk of neural and vascular cells regulates blood vessel ingression into the CNS and the formation of a fully functional BBB. Ultimately, understanding these signaling pathways will reveal how a defective neurovascular unit impacts on CNS function during aging and in neurological disease. It will also benefit the development of new therapeutic strategies aimed at restoring or improving vascular supply to ischemic retina and brain in diseases such as diabetic retinopathy, age-related neurodegeneration 
and stroke. In the mature brain, neuronal activity stimulates changes in blood flow that can be measured by fMRI, but how this flow information is sensed and leads to structural changes in blood vessels is largely unknown and therefore requires further research. Finally, the specific features of the tumor microenvironment that promote the differentiation of tumor cells into endothelium, and the functional consequence of this transdifferentiation for glioblastoma remain to be determined.

Acknowledgments We thank Dr. Sophie DalPra for artwork and Alessandro Fantin for critical reading of the manuscript. This work was supported by NIH grants to V.L.B. [R01 HL43174 and HL86465] and a Wellcome Trust Investigator Award to C.R. [095623/Z/11/Z].

Open Access This article is distributed under the terms of the Creative Commons Attribution License which permits any use, distribution, and reproduction in any medium, provided the original author(s) and the source are credited.

\section{References}

1. Feeney J, Watterson R (1946) The development of the vascular pattern within the walls of the central nervous system of the chick embryo. J Morphol 78:231-304

2. Strong L (1964) The early embryonic pattern of internal vascularization of the mammalian cerebral cortex. J Comp Neurol 123:121-138

3. BarT (1983) Patterns of vascularization in the developing cerebral cortex. Ciba Found Symp 100:20-36

4. Nakao T, Ishizawa A, Ogawa R (1988) Observations of vascularization in the spinal cord of mouse embryos, with special reference to development of boundary membranes and perivascular spaces. Anat Rec 221:663-677

5. Pardanaud L, Altmann C, Kitos P, Dieterlen-Lievre F, Buck CA (1987) Vasculogenesis in the early quail blastodisc as studied with a monoclonal antibody recognizing endothelial cells. Development 100:339-349

6. Poole TJ, Coffin JD (1988) Developmental Angiogenesis: quail embryonic vasculature. Scanning Microsc 2(1):443-448

7. Wilting J, Brand-Saberi B, Huang R, Zhi Q, Kontges G, Ordahl CP, Christ B (1995) Angiogenic potential of the avian somite. Dev Dyn 202:165-171

8. Pardanaud L, Luton D, Prigent M, Bourcheix LM, Catala M, Dieterlen-Lievre F (1996) Two distinct endothelial lineages in ontogeny, one of them related to hemopoiesis. Development 122:1363-1371

9. Kurz H, Gartner T, Eggli PS, Christ B (1996) First blood vessels in the avian neural tube are formed by a combination of dorsal angioblast immigration and ventral sprouting of endothelial cells. Dev Biol 173(1):133-147. doi:10.1006/dbio.1996.00 12S0012-1606(96)90012-3

10. James JM, Gewolb C, Bautch VL (2009) Neurovascular development uses VEGF-A signaling to regulate blood vessel ingression into the neural tube. Development 136(5):833-841. doi:10. 1242/dev.028845

11. Itasaki N, Bel-Vialar S, Krumlauf R (1999) 'Shocking' developments in chick embryology: electroporation and in ovo gene expression. Nat Cell Biol 1:E203-E207

12. Cogan DG (1963) Development and senescence of the human retinal vasculature. Trans Ophthalmol Soc U K 83:465-489
13. Michaelson IC (1954) Retinal circulation in man and animals. vol 14, Springfield, IL: Thomas, pp 118-131

14. Fruttiger M (2007) Development of the retinal vasculature. Angiogenesis 10(2):77-88. doi:10.1007/s10456-007-9065-1

15. Ruhrberg C, Gerhardt H, Golding M, Watson R, Ioannidou S, Fujisawa H, Betsholtz C, Shima DT (2002) Spatially restricted patterning cues provided by heparin-binding VEGFA control blood vessel branching morphogenesis. Genes Dev 16(20):2684-2698. doi:10.1101/gad.242002

16. Lawson ND, Weinstein BM (2002) In vivo imaging of embryonic vascular development using transgenic zebrafish. Dev Biol 248(2):307-318. p[ii]:S0012160602907116

17. Isogai S, Horiguchi M, Weinstein BM (2001) The vascular anatomy of the developing zebrafish: an atlas of embryonic and early larval development. Dev Biol (N Y 1985) 230(2):278-301. doi:1 0.1006/dbio.2000.9995

18. Fantin A, Vieira JM, Gestri G, Denti L, Schwarz Q, Prykhozhij S, Peri F, Wilson SW, Ruhrberg C (2010) Tissue macrophages act as cellular chaperones for vascular anastomosis downstream of VEGF-mediated endothelial tip cell induction. Blood 116(5):829-840. doi:10.1182/blood-2009-12-257832

19. Noden DM (1990) Origins and assembly of avian embryonic blood vessels. Ann N Y Acad Sci 588:236-249

20. Cossmann PH, Eggli PS, Christ B, Kurz H (1997) Mesodermderived cells proliferate in the embryonic central nervous system: confocal microscopy and three-dimensional visualization. Histochem Cell Biol 107(3):205-213

21. Fruttiger M, Calver AR, Kruger WH, Mudhar HS, Michalovich D, Takakura N, Nishikawa S, Richardson WD (1996) PDGF mediates a neuron-astrocyte interaction in the developing retina. Neuron 17(6):1117-1131. p[ii]:S0896-6273(00)80244-5

22. Ling TL, Stone J (1988) The development of astrocytes in the cat retina: evidence of migration from the optic nerve. Brain Res 44(1):73-85

23. West H, Richardson WD, Fruttiger M (2005) Stabilization of the retinal vascular network by reciprocal feedback between blood vessels and astrocytes. Development 132(8):1855-1862. doi:10.1242/dev.01732

24. Kubota Y, Takubo K, Shimizu T, Ohno H, Kishi K, Shibuya M, Saya H, Suda T (2009) M-CSF inhibition selectively targets pathological angiogenesis and lymphangiogenesis. J Exp Med 206(5):1089-1102. doi:10.1084/jem.20081605

25. Rymo SF, Gerhardt H, Wolfhagen Sand F, Lang R, Uv A, Betsholtz C (2011) A two-way communication between microglial cells and angiogenic sprouts regulates angiogenesis in aortic ring cultures. PLoS One 6(1):e15846. doi:10.1371/ journal.pone. 0015846

26. Tammela T, Zarkada G, Nurmi H, Jakobsson L, Heinolainen K, Tvorogov D, Zheng W, Franco CA, Murtomaki A, Aranda E, Miura N, Yla-Herttuala S, Fruttiger M, Makinen T, Eichmann A, Pollard JW, Gerhardt H, Alitalo K (2011) VEGFR-3 controls tip to stalk conversion at vessel fusion sites by reinforcing Notch signalling. Nat Cell Biol 13(10):1202-1213. doi:10.1038/ncb2331

27. Walls GL (1942) The vertebrate eye and its adaptive radiation. Cranbrook Institute of Science, Bloomfield Hills

28. Vasudevan A, Long J, Crandell J, Rubenstein J, Bhide P (2008) Compartment-specific transcription factors orchestrate angiogenesis gradients in the embryonic brain. Nat Neurosci 11:429-431

29. Bussmann J, Wolfe SA, Siekmann AF (2011) Arterial-venous network formation during brain vascularization involves hemodynamic regulation of chemokine signaling. Development 138(9):1717-1726. doi:10.1242/dev.059881

30. Ulrich F, Ma LH, Baker RG, Torres-Vazquez J (2011) Neurovascular development in the embryonic zebrafish hindbrain. Dev Biol 357(1):134-151 
31. Heyman I, Faissner A, Lumsden A (1995) Cell and matrix specialisations of rhombomere boundaries. Dev Dyn 204(3):301315. doi:10.1002/aja.1002040308

32. Heyman I, Kent A, Lumsden A (1993) Cellular morphology and extracellular space at rhombomere boundaries in the chick embryo hindbrain. Dev Dyn 198(4):241-253. doi:10.1002/ aja. 1001980402

33. Geudens I, Gerhardt H (2011) Coordinating cell behaviour during blood vessel formation. Development 138(21):4569-4583. doi:10.1242/dev.062323

34. Gerhardt H, Golding M, Fruttiger M, Ruhrberg C, Lundkvist A, Abramsson A, Jeltsch M, Mitchell C, Alitalo K, Shima D, Betsholtz C (2003) VEGF guides angiogenic sprouting utilizing endothelial tip cell filopodia. J Cell Biol 161(6):1163-1177. doi :10.1083/jcb.200302047

35. Hellstrom M, Phng LK, Gerhardt H (2007) VEGF and Notch signaling: the yin and yang of angiogenic sprouting. Cell Adh Migr 1(3):133-136 pii: 4978

36. Suchting S, Freitas C, le Noble F, Benedito R, Breant C, Duarte A, Eichmann A (2007) The Notch ligand Delta-like 4 negatively regulates endothelial tip cell formation and vessel branching. Proc Natl Acad Sci USA 104(9):3225-3230. doi:10.1073/p nas.0611177104

37. Leslie JD, Ariza-McNaughton L, Bermange AL, McAdow R, Johnson SL, Lewis J (2007) Endothelial signalling by the Notch ligand Delta-like 4 restricts angiogenesis. Development 134(5):839-844. doi:10.1242/dev.003244

38. Jakobsson L, Franco CA, Bentley K, Collins RT, Ponsioen B, Aspalter IM, Rosewell I, Busse M, Thurston G, Medvinsky A, Schulte-Merker S, Gerhardt H (2010) Endothelial cells dynamically compete for the tip cell position during angiogenic sprouting. Nat Cell Biol 12(10):943-953. doi: $10.1038 / \mathrm{ncb} 2103$

39. Larrivee B, Prahst C, Gordon E, del Toro R, Mathivet T, Duarte A, Simons M, Eichmann A (2012) ALK1 signaling inhibits angiogenesis by cooperating with the Notch pathway. Dev Cell 22(3):489-500. doi:10.1016/j.devcel.2012.02.005

40. Moya IM, Umans L, Maas E, Pereira PN, Beets K, Francis A, Sents W, Robertson EJ, Mummery CL, Huylebroeck D, Zwijsen A (2012) Stalk cell phenotype depends on integration of Notch and Smad1/5 signaling cascades. Dev Cell 22(3):501-514. doi:10.1016/j.devcel.2012.01.007

41. Wiley DM, Kim JD, Hao J, Hong CC, Bautch VL, Jin SW (2011) Distinct signalling pathways regulate sprouting angiogenesis from the dorsal aorta and the axial vein. Nat Cell Biol 13(6):686-692. doi:10.1038/ncb2232

42. Kim JD, Kang H, Larrivee B, Lee MY, Mettlen M, Schmid SL, Roman BL, Qyang Y, Eichmann A, Jin SW (2012) Contextdependent proangiogenic function of bone morphogenetic protein signaling is mediated by disabled homolog 2. Dev Cell 23(2):441-448. doi:10.1016/j.devcel.2012.07.007

43. Del Toro R, Prahst C, Mathivet T, Siegfried G, Kaminker JS, Larrivee B, Breant C, Duarte A, Takakura N, Fukamizu A, Penninger J, Eichmann A (2010) Identification and functional analysis of endothelial tip cell-enriched genes. Blood. doi:10.1182/blood-2010-02-270819

44. Strasser GA, Kaminker JS, Tessier-Lavigne M (2010) Microarray analysis of retinal endothelial tip cells identifies CXCR4 as a mediator of tip cell morphology and branching. Blood 115(24):5102-5110. doi:10.1182/blood-2009-07-230284

45. McCarty JH (2009) Cell adhesion and signaling networks in brain neurovascular units. Curr Opin Hematol 16(3):209-214. doi:10.1097/MOH.0b013e32832a07eb

46. Lok J, Gupta P, Guo S, Kim WJ, Whalen MJ, van Leyen K, Lo EH (2007) Cell-cell signaling in the neurovascular unit. Neurochem Res 32:2032-2045
47. Seidner G, Alvarez MG, Yeh JI, O'Driscoll KR, Klepper J, Stump TS, Wang D, Spinner NB, Birnbaum MJ, De Vivo DC (1998) GLUT-1 deficiency syndrome caused by haploinsufficiency of the blood-brain barrier hexose carrier. Nat Genet 18(2):188-191. doi:10.1038/ng0298-188

48. Armulik A, Genove G, Mae M, Nisancioglu MH, Wallgard E, Niaudet C, He L, Norlin J, Lindblom P, Strittmatter K, Johansson BR, Betsholtz C (2010) Pericytes regulate the blood-brain barrier. Nature 468(7323):557-561

49. Daneman R, Zhou L, Kebede AA, Barres BA (2010) Pericytes are required for blood-brain barrier integrity during embryogenesis. Nature 468(7323):562-566

50. Li F, Lan Y, Wang Y, Wang J, Yang G, Meng F, Han H, Meng A, Wang Y, Yang X (2011) Endothelial smad4 maintains cerebrovascular integrity by activating $\mathrm{n}$-cadherin through cooperation with notch. Dev Cell 20(3):291-302

51. Arnold TD, Ferrero GM, Qiu H, Phan IT, Akhurst RJ, Huang EJ, Reichardt LF (2012) Defective retinal vascular endothelial cell development as a consequence of impaired integrin alphavbeta8mediated activation of transforming growth factor-b. J Neurosci 32(4):1197-1206. doi:10.1523/jneurosci.5648-11.2012

52. Hirota S, Liu Q, Lee HS, Hossain MG, Lacy-Hulbert A, McCarty JH (2011) The astrocyte-expressed integrin alpha v beta 8 governs blood vessel sprouting in the developing retina. Development 138(23):5157-5166. doi:10.1242/dev.069153

53. Allinson KR, Lee HS, Fruttiger M, McCarty J, Arthur HM (2012) Endothelial expression of TGF $\beta$ type II receptor is required to maintain vascular integrity during postnatal development of the central nervous system. PLoS One 7(6):e39336

54. Haigh JJ, Morelli PI, Gerhardt H, Haigh K, Tsien J, Damert A, Miquerol L, Muhlner U, Klein R, Ferrara N, Wagner EF, Betsholtz C, Nagy A (2003) Cortical and retinal defects caused by dosage-dependent reductions in VEGF-A paracrine signaling. Dev Biol 262(2):225-241

55. Raab S, Beck H, Gaumann A, Yuce A, Gerber HP, Plate K, Hammes HP, Ferrara N, Breier G (2004) Impaired brain angiogenesis and neuronal apoptosis induced by conditional homozygous inactivation of vascular endothelial growth factor. Thromb Haemost 91(3):595-605

56. Provis JM, Leech J, Diaz CM, Penfold PL, Stone J, Keshet E (1997) Development of the human retinal vasculature: cellular relations and VEGF expression. Exp Eye Res 65(4):555-568

57. Stone J, Itin A, Alon T, Pe'er J, Gnessin H, Chan-Ling T, Keshet E (1995) Development of retinal vasculature is mediated by hypoxia-induced vascular endothelial growth factor (VEGF) expression by neuroglia. J Neurosci 15(7 Pt 1):4738-4747

58. Park JE, Keller GA, Ferrara N (1993) The vascular endothelial growth factor (VEGF) isoforms: differential deposition into the subepithelial extracellular matrix and bioactivity of extracellular matrix-bound VEGF. Mol Biol Cell 4(12):1317-1326

59. Houck KA, Leung DW, Rowland AM, Winer J, Ferrara N (1992) Dual regulation of vascular endothelial growth factor bioavailability by genetic and proteolytic mechanisms. J Biol Chem 267(36):26031-26037

60. Lee S, Jilani SM, Nikolova GV, Carpizo D, Iruela-Arispe ML (2005) Processing of VEGF-A by matrix metalloproteinases regulates bioavailability and vascular patterning in tumors. J Cell Biol 169(4):681-691. doi:10.1083/jcb.200409115

61. StenzelD, LundkvistA, SauvagetD, Busse M, Graupera M, van der Flier A, Wijelath ES, Murray J, Sobel M, Costell M, Takahashi S, Fassler R, Yamaguchi Y, Gutmann DH, Hynes RO, Gerhardt H (2011) Integrin-dependent and -independent functions of astrocytic fibronectin in retinal angiogenesis. Development 138(20): 4451-4463. doi:10.1242/dev.071381

62. Scott A, Powner MB, Gandhi P, Clarkin C, Gutmann DH, Johnson RS, Ferrara N, Fruttiger M (2010) Astrocyte-derived vascular 
endothelial growth factor stabilizes vessels in the developing retinal vasculature. PLoS ONE 5(7):e11863. doi:10.1371/ journal.pone. 0011863

63. Weidemann A, Krohne TU, Aguilar E, Kurihara T, Takeda N, Dorrell MI, Simon MC, Haase VH, Friedlander M, Johnson RS (2010) Astrocyte hypoxic response is essential for pathological but not developmental angiogenesis of the retina. Glia 58(10):1177-1185. doi:10.1002/glia.20997

64. Koch S, Tugues S, Li X, Gualandi L, Claesson-Welsh L (2011) Signal transduction by vascular endothelial growth factor receptors. Biochem J 437(2):169-183. doi:10.1042/BJ20110301

65. Benedito R, Rocha SF, Woeste M, Zamykal M, Radtke F, Casanovas O, Duarte A, Pytowski B, Adams RH (2012) Notchdependent VEGFR3 upregulation allows angiogenesis without VEGF-VEGFR2 signalling. Nature 484(7392):110-114. doi: 10.1038 /nature 10908

66. Kawasaki T, Kitsukawa T, Bekku Y, Matsuda Y, Sanbo M, Yagi T, Fujisawa H (1999) A requirement for neuropilin-1 in embryonic vessel formation. Development 126(21):4895-4902

67. Gerhardt H, Ruhrberg C, Abramsson A, Fujisawa H, Shima D, Betsholtz C (2004) Neuropilin-1 is required for endothelial tip cell guidance in the developing central nervous system. Dev Dyn 231(3):503-509. doi:10.1002/dvdy.20148

68. Gu C, Rodriguez ER, Reimert DV, Shu T, Fritzsch B, Richards LJ, Kolodkin AL, Ginty DD (2003) Neuropilin-1 conveys semaphorin and VEGF signaling during neural and cardiovascular development. Dev Cell 5(1):45-57

69. Schwarz Q, Ruhrberg C (2010) Neuropilin, you gotta let me know: should I stay or should I go? Cell Adh Migr 4(1):61-66

70. Appleton BA, Wu P, Maloney J, Yin J, Liang WC, Stawicki S, Mortara K, Bowman KK, Elliott JM, Desmarais W, Bazan JF, Bagri A, Tessier-Lavigne M, Koch AW, Wu Y, Watts RJ, Wiesmann C (2007) Structural studies of neuropilin/antibody complexes provide insights into semaphorin and VEGF binding. EMBO J 26(23):4902-4912. doi:10.1038/sj.emboj.7601906

71. Parker MW, Xu P, Li X, Vander Kooi CW (2012) Structural basis for selective vascular endothelial growth factor-A (VEGFA) binding to neuropilin-1. J Biol Chem 287(14):11082-11089. doi:10.1074/jbc.M111.331140

72. Vieira JM, Schwarz Q, Ruhrberg C (2007) Selective requirements for NRP1 ligands during neurovascular patterning. Development 134(10):1833-1843. doi:10.1242/dev.002402

73. Bouvree K, Brunet I, Del Toro R, Gordon E, Prahst C, Cristofaro B, Mathivet T, Xu Y, Soueid J, Fortuna V, Miura N, Aigrot MS, Maden CH, Ruhrberg C, Thomas JL, Eichmann A (2012) Semaphorin3A, Neuropilin-1, and PlexinA1 are required for lymphatic valve formation. Circ Res 111(4):437-445. doi:10.1161/CIRCR ESAHA.112.269316

74. Gu C, Yoshida Y, Livet J, Reimert DV, Mann F, Merte J, Henderson CE, Jessell TM, Kolodkin AL, Ginty DD (2005) Semaphorin $3 \mathrm{E}$ and Plexin-D1 control vascular pattern independently of neuropilins. Science 307(5707):265-268

75. Maione F, Molla F, Meda C, Latini R, Zentilin L, Giacca M, Seano G, Serini G, Bussolino F, Giraudo E (2009) Semaphorin $3 \mathrm{~A}$ is an endogenous angiogenesis inhibitor that blocks tumor growth and normalizes tumor vasculature in transgenic mouse models. J Clin Invest 119(11):3356-3372

76. Acevedo LM, Barillas S, Weis SM, Gothert JR, Cheresh DA (2008) Semaphorin 3A suppresses VEGF-mediated angiogenesis yet acts as a vascular permeability factor. Blood 111(5):26742680. doi:10.1182/blood-2007-08-110205

77. Murga M, Fernandez-Capetillo O, Tosato G (2005) Neuropilin-1 regulates attachment in human endothelial cells independently of vascular endothelial growth factor receptor-2. Blood 105(5):1992-1999. doi:10.1182/blood-2004-07-2598
78. West DC, Rees CG, Duchesne L, Patey SJ, Terry CJ, Turnbull JE, Delehedde M, Heegaard CW, Allain F, Vanpouille C, Ron D, Fernig DG (2005) Interactions of multiple heparin binding growth factors with neuropilin-1 and potentiation of the activity of fibroblast growth factor-2. J Biol Chem 280(14):13457-13464

79. CastellaniV,ChedotalA,SchachnerM,Faivre-SarrailhC,RougonG (2000) Analysis of the L1-deficient mouse phenotype reveals cross-talk between Sema3A and L1 signaling pathways in axonal guidance. Neuron 27(2):237-249

80. Fukasawa M, Matsushita A, Korc M (2007) Neuropilin-1 interacts with integrin betal and modulates pancreatic cancer cell growth, survival and invasion. Cancer Biol Ther 6(8):1173-1180 pii: 4363

81. Valdembri D, Caswell PT, Anderson KI, Schwarz JP, Konig I, Astanina E, Caccavari F, Norman JC, Humphries MJ, Bussolino F, Serini G (2009) Neuropilin-1/GIPC1 signaling regulates alpha5 beta1 integrin traffic and function in endothelial cells. PLoS Biol 7(1):e25. doi:10.1371/journal.pbio.1000025

82. Kim J, Oh WJ, Gaiano N, Yoshida Y, Gu C (2011) Semaphorin 3E-Plexin-D1 signaling regulates VEGF function in developmental angiogenesis via a feedback mechanism. Genes Dev 25(13):1399-1411. doi:10.1101/gad.2042011

83. Chauvet S, Cohen S, Yoshida Y, Fekrane L, Livet J, Gayet O, Segu L, Buhot MC, Jessell TM, Henderson CE, Mann F (2007) Gating of Sema3E/PlexinD1 signaling by neuropilin-1 switches axonal repulsion to attraction during brain development. Neuron 56(5):807-822. doi:10.1016/j.neuron.2007.10.019

84. Fukushima Y, Okada M, Kataoka H, Hirashima M, Yoshida Y, Mann F, Gomi F, Nishida K, Nishikawa S, Uemura A (2011) Sema3E-PlexinD1 signaling selectively suppresses disoriented angiogenesis in ischemic retinopathy in mice. J Clin Investig 121(5):1974-1985. doi:10.1172/JCI44900

85. Stenman JM, Rajagopal J, Carroll TJ, Ishibashi M, McMahon J, McMahon AP (2008) Canonical Wnt signaling regulates organspecific assembly and differentiation of CNS vasculature. Science 322(5905):1247-1250. doi:10.1126/science.1164594

86. Daneman R, Agalliu D, Zhou L, Kuhnert F, Kuo CJ, Barres BA (2009) Wnt/beta-catenin signaling is required for CNS, but not non-CNS, angiogenesis. Proc Natl Acad Sci 106(2):641-646. doi:10.1073/pnas.0805165106

87. Tam SJ, Richmond DL, Kaminker JS, Modrusan Z, MartinMcNulty B, Cao TC, Weimer RM, Carano RAD, van Bruggen N, Watts RJ (2012) Death receptors DR6 and TROY regulate brain vascular development. Dev Cell 22(2):403-417

88. Cullen M,Elzarrad MK, Seaman S, Zudaire E, Stevens J, Yang MY, Li X, Chaudhary A, Xu L, Hilton MB, Logsdon D, Hsiao E, Stein EV, Cuttitta F, Haines DC, Nagashima K, Tessarollo L, St. Croix B (2011) GPR124, an orphan G protein-coupled receptor, is required for CNS-specific vascularization and establishment of the blood-brain barrier. Proc Natl Acad Sci 108 (14):57595764. doi:10.1073/pnas.1017192108

89. Kuhnert F, Mancuso MR, Shamloo A, Wang H-T, Choksi V, Florek M, Su H, Fruttiger M, Young WL, Heilshorn SC, Kuo CJ (2010) Essential regulation of CNS angiogenesis by the orphan G protein-coupled receptor GPR124. Science 330(6006):985989. doi:10.1126/science.1196554

90. Anderson KD, Pan L, Yang XM, Hughes VC, Walls JR, Dominguez MG, Simmons MV, Burfeind P, Xue Y, Wei Y, Macdonald LE, Thurston G, Daly C, Lin HC, Economides AN, Valenzuela DM, Murphy AJ, Yancopoulos GD, Gale NW (2011) Angiogenic sprouting into neural tissue requires Gpr124, an orphan G protein-coupled receptor. Proc Natl Acad Sci 108(7):2807-2812. doi:10.1073/pnas.1019761108

91. Nguyen H-L, Lee YJ, Shin J, Lee E, Park SO, McCarty JH, Oh SP (2011) TGF-[beta] signaling in endothelial cells, but not 
neuroepithelial cells, is essential for cerebral vascular development. Lab Invest 91(11):1554-1563

92. McCarty JH, Lacy-Hulbert A, Charest A, Bronson RT, Crowley D, Housman D, Savill J, Roes J, Hynes RO (2005) Selective ablation of alphav integrins in the central nervous system leads to cerebral hemorrhage, seizures, axonal degeneration and premature death. Development 132(1):165-176. doi:10.1242/dev.01551

93. Segura I, De Smet F, Hohensinner PJ, de Ruiz Almodovar C, Carmeliet P (2009) The neurovascular link in health and disease: an update. Trends Mol Med 15(10):439-451.doi:10.1016/ j.molmed.2009.08.005

94. Plummer N, Zawistowski J, Marchuk D (2005) Genetics of cerebral cavernous malformations. Curr Neurol Neurosci 5:391-396

95. Revencu N, Vikkula M (2006) Cerebral cavernous malformation: new molecular and clinical insights. J Med Genet 43(9):716721. doi:10.1136/jmg.2006.041079

96. McDonald DA, Shenkar R, Shi C, Stockton RA, Akers AL, Kucherlapati MH, Kucherlapati R, Brainer J, Ginsberg MH, Awad IA, Marchuk DA (2011) A novel mouse model of cerebral cavernous malformations based on the two-hit mutation hypothesis recapitulates the human disease. Human Mol Genet 20(2):211-222. doi:10.1093/hmg/ddq433

97. Stockton RA, Shenkar R, Awad IA, Ginsberg MH (2010) Cerebral cavernous malformations proteins inhibit Rho kinase to stabilize vascular integrity. J Exp Med 207(4):881-896. doi:10.1 084/jem.20091258
98. Takano S (2012) Glioblastoma angiogenesis: vEGF resistance solutions and new strategies based on molecular mechanisms of tumor vessel formation. Brain Tumor Pathol 29(2):73-86. doi:10.1007/s10014-011-0077-6

99. Jain RK, di Tomaso E, Duda DG, Loeffler JS, Sorensen AG, Batchelor TT (2007) Angiogenesis in brain tumours. Nat Rev Neurosci 8(8):610-622. doi:10.1038/nrn2175

100. El Hallani S, Boisselier B, Peglion F, Rousseau A, Colin C, Idbaih A, Marie Y, Mokhtari K, Thomas JL, Eichmann A, Delattre JY, Maniotis AJ, Sanson M (2010) A new alternative mechanism in glioblastoma vascularization: tubular vasculogenic mimicry. Brain 133(Pt 4):973-982. doi:10.1093/brain/awq044

101. Ricci-Vitiani L, Pallini R, Biffoni M, Todaro M, Invernici G, Cenci T, Maira G, Parati EA, Stassi G, Larocca LM, De Maria R (2010) Tumour vascularization via endothelial differentiation of glioblastoma stem-like cells. Nature 468(7325):824-828

102. Soda Y, Marumoto T, Friedmann-Morvinski D, Soda M, Liu F, Michiue H, Pastorino S, Yang M, Hoffman RM, Kesari S, Verma IM (2011) Transdifferentiation of glioblastoma cells into vascular endothelial cells. Proc Natl Acad Sci USA 108(11):42744280. doi:10.1073/pnas. 1016030108

103. Wang R, Chadalavada K, Wilshire J, Kowalik U, Hovinga KE, Geber A, Fligelman B, Leversha M, Brennan C, Tabar V (2010) Glioblastoma stem-like cells give rise to tumour endothelium. Nature 468(7325):829-833. doi:10.1038/nature09624 